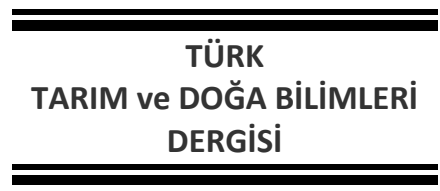

\title{
Farklı Ekim Zamanlarında Yetiştirilen Nohut Bitkilerinin Kök Büyümesinin Weibull Modeli ile Tahmini
}

\author{
Ufuk KARADAVUT*, Ömer SÖZEN, Mehmet YAĞMUR \\ Ahi Evran Üniversitesi, Ziraat Fakültesi, Kırşehir \\ *Sorumlu yazar: ufukkaradavut@gmail.com
}

Geliş Tarihi: 05.09.2019

Düzeltme Geliş Tarihi: 03.10.2019

Kabul Tarihi: 04.10.2019

\section{Özet}

Bitkisel üretimde verim öncelikli olarak ele alınan konudur. Ancak verim ele alınırken, genellikle verime etki eden toprak üstü karakterler dikkate alınmaktadır. Yapılan bu çalışmada kök büyümesinin bitki büyüme ve gelişmesindeki önemine bağlı olarak nasıl bir kuru madde birikimi geliştirdiğini belirleyerek bunu büyüme modeli ile tahminlemeye çalışımıştır. Bunun için dinamik bir model olan iki, üç ve dört parametreli Weibull modelleri kullanılmıştır. Bitki materyali olarak Azkan nohut çeşidi kullanılmıştır. Üç farklı zamanda ekimi yapılan bitkilerin kökleri alınarak taze ve kuru ağrılıkları saptanmıştır. Ayrıca büyüme oranı, büküm noktası, büyümenin başlangıç noktası ve üst asimptot değerleri belirlenmiştir. Karşılaştırma ölçütleri olarak da belirleme katsayısı $\left(R^{2}\right)$, hata kareler ortalamasının karekökü $(R M S E)$ ve ki kare $\left(\chi^{2}\right)$ değeri kullanıımıştır. Sonuç olarak gerek kök taze ağırlığında ve gerekse de kök kuru ağırlıklarında dört parametreli Weibull modelinin diğer modellere göre daha başarılı olduğu tespit edilmiştir. İki parametreli modelin ise en düşük uyumu gösterdiği görülmüştür. Ekim zamanları bakımından ise en yüksek tahminleme başarısı ikinci ekim zamanında olurken, en düşük tahminleme başarısı ise üçüncü ekim zamanında olmuştur.

Anahtar kelimeler: Nohut, Weibull, model, ekim zamanı.

\section{Estimation of Root Growth of Chickpea Plants Grown At Different Sowing Times with Weibull Model}

\begin{abstract}
In crop production, yield is a matter of priority. However, when considering the yield, the above-ground characteristics which generally affect the yield are taken into consideration. In this study, depending on the importance of root growth in plant growth and development, we tried to predict how it developed a dry matter briquette. For this we used a dynamic model of Weibull models with two, three and four parameters. Azkan chickpea variety was used as plant material. The roots of the plants which were planted at three different times were taken and their fresh and dry weights were observed. In addition, growth rate, bending point, starting point of growth and upper asymptote values were determined. The coefficient of determination $\left(R^{2}\right)$, root of square mean square error ( $R M S E)$ and chi square $\left(\chi^{2}\right)$ of were used as comparison criteria. As a result, it was determined that Weibull model with four parameters was more successful than other models in both root fresh weight and root dry weights. Two-parameter model was found to be most successful. In terms of sowing times, the highest estimation success was in the second sowing period, while the lowest estimation success was in the third sowing period.
\end{abstract}

Key words: Chickpea, Weibull, model, sowing time. 


\section{Giriş}

Bitkisel üretim, gelişmiş ya da gelişmekte olan bütün ülkeler için vazgeçilmez bir kaynaktır. Bitkisel üretimde temel amaç mümkün olan en az girdi ile en yüksek verimi alabilmektir. Bunun içinde yoğun olarak çalışmalar yapılmaktadır. Nüfus artışı nedeniyle yaşadığımız dünyanın taşıyabileceği yük artmaktadır. Elbette bu bitkisel üretimin önemini daha da artırmaktadır. Bununla birlikte elde edilen ürünlerin sadece miktarı değil, kalitesinin arttırılması için çalışılmaktadır. Bitki gelişimi toprak üstü ve toprak altı büyüme olarak iki kısımda incelenmektedir (Foy, 1992). Bitki gelişiminde öncelik her zaman için kök gelişiminde olmuştur. Kök gelişimi başarılı olan bitkilerin toprak üstü gelişimleri de başarılı olmaktadır (Adams ve Moore, 1983). Aynı zamanda bitkilerin ileriki dönemlerde yaşayabilecekleri stres faktörlerine karşı toleransları da artmaktadır (El-Ghamery ve ark., 2003). Ancak bitkiler herhangi bir şekilde olumsuz etki altında kaldığında ise doku ve organlarda büyüme yavaşlamakta aynı oranda vejetatif ve generatif organlarının gelişimi de olumsuz yönde etkilenmektedir (Gür ve ark., 2004). En çok etkilenen ise toprak altı kısımları olmaktadır (Jain ve ark., 2000).

Toprak oldukça aktif bir yapıya sahiptir. Çünkü bünyesinde sayıca ve çeşitlik bakımından çok sayıda mikroorganizmaları barındırır. Bu mikroorganizmalar bitki kökleri ile sürekli olarak etkileşim halinde olurlar. Bu etkileşiminin olumlu ya da olumsuz olması aynı zamanda kök gelişimini ve buna bağıı olarak da toprak üstü gelişimini doğrudan etkiler (Romerio, 2000; Altın ve Bora 2005). Çünkü embriyodan sonrası için bitki gelişimi, temel olarak apikalde yer edinmiş kök hücreleri tarafından yönlendirilir (Singh ve Bhalla, 2006). Bu nedenle kök bölgesi bitkilerin en hassas oldukları bölge olarak kabul edilir (Saleque ve Kirk, 1995; Reynolds ve D'Antonio, 1996). Köklerin sahip oldukları özel yapılar bitkilerin morfolojilerini ve organ gelişimlerini karşılaşılan çevresel koşullara uyarlamalarını sağlar (Malamy, 2005).

Kök sisteminin yapısı bitki türlerine, toprak yapısına, topraktaki su ve besin maddesi miktarına göre değişiklikler gösterir (Hodge ve ark., 2009). Bu değişikliklerin izlenmesi ve olabilecek değişimlerin bitkinin büyümesinde, gelişmesinde ve verimliliğinde nasıl bir değişimin olacağının bilinmesi faydalı olur. Bunun içinde değişimleri önceden belirleyebilmek için kökün büyüme ve gelişmesinin tahmini yapılmak istenir (Karadavut ve ark., 2010a). Bunun içinde kullanılan çok sayıda matematiksel model bulunmaktadır (Karadavut ve Tozluca, 2005; Prasad ve ark 2008). Weibull modeli bu modellerden birsidir (Karadavut ve ark., 2010b). Weibull modeli dinamik bir modeldir ve bu özelliğinden dolayı çok farklı alanlarda başarılı bir şekilde kullanılabilmektedir (Murthy ve ark., 2004; Mahanta ve Borah, 2014). Bu tür çalışmalarda orijinal verinin kullanılmasından ziyade üretilen değerler ile benzetim (simülasyon) çalışmaları yapılmaktadır (Ratkowsky, 1983). Ancak simulasyon verileri gerçek veriler kadar güvenilir olmadığı gibi hata da yüksek olmaktadır. Bu nedenle gerçek veriler ile yapılacak olan çalışmaların daha faydalı olacağı bilinmektedir (Fekeduleng ve ark., 1999). Yaptığımız bu çalışmada gerçek verilerin yorumlanmasıyla nohut bitkilerinde weibull modeli kullanılarak model parametrelerinin tahmin edilmesi amaçlanmıştır. Böylece bitkilerin kök büyümesinin çevre faktörlerine göre başarılı bir şekilde tahminleme yaparak üretimi başarılı bir şekilde yönlendirmeye katkı sağlamak bu çalışmanın amacını oluşturmuştur.

\section{Materyal ve Yöntem}

Nohut bitkilerinin kök büyümesinin önceden tahmin edilmesinin belirlenebilmesi amacıyla yürütülen bu çalışma 2013 ve 2014 yıllarında 2 yıl süre ile Ahi Evran Üniversitesi Araştırma ve Uygulama Arazisine ait deneme sahasında gerçekleştirilmiştir.

Çizelge 1. Kırşehir iline ait iklim verileri*

\begin{tabular}{|c|c|c|c|c|c|c|c|c|c|}
\hline \multirow{2}{*}{ Aylar } & \multicolumn{3}{|c|}{ Ortalama sıcaklık $\left({ }^{\circ} \mathrm{C}\right)$} & \multicolumn{3}{|c|}{ Toplam yağış (mm) } & \multicolumn{3}{|c|}{ Ortalama nisbi nem (\%) } \\
\hline & 2013 & 2014 & Uzun Yillar & 2013 & 2014 & Uzun Yillar & 2013 & 2014 & Uzun Yillar \\
\hline Mart & 7.2 & 7.4 & 6.3 & 14.2 & 52.2 & 9.3 & 63 & 64.3 & 67.5 \\
\hline Nisan & 12 & 13.2 & 11.4 & 45.1 & 20.2 & 7.7 & 62.8 & 54.9 & 59.7 \\
\hline Mayıs & 19.3 & 16.9 & 16.2 & 15.1 & 46.6 & 10.7 & 44.7 & 59.5 & 56.2 \\
\hline Haziran & 21.4 & 20.8 & 20.6 & 1 & 36 & 13.9 & 42 & 51.6 & 50.9 \\
\hline Temmuz & 24.1 & 27.6 & 24.8 & 6.6 & 13 & 2.9 & 37.1 & 33.6 & 38.4 \\
\hline Ortalama & 16.8 & 17.2 & 15.9 & & & & 52.5 & 52.8 & 54.5 \\
\hline Toplam & & & & 82 & 168 & 44.5 & & & \\
\hline
\end{tabular}


Araştırmanın iki yıl süresince yürütüldüğü deneme arazisindeki toprak analizi sonucunda pH'ın 7.72, toprak yapısının tınlı yapıda, organik madde içeriğinin 1.75 ile düşük seviyede kaldığı, kireç bakımından orta derecede (\% 15.34) ve tuzsuz yapıda olduğu, potasyum içeriği bakımından yeterli seviyede $(1.44 \mathrm{Me} / 100 \mathrm{~g})$, fosfor bakımından ise yetersiz durumda kaldığı (2.16 ppm) belirlenmiştir (Kaçar, 1995).

İç Anadolu Bölgesinde yer alan Kırşehir ili'nde yazlar sıcak ve kurak, baharlar yağmurlu, kış ise sert ve soğuk geçer. Çalışmanın yürütüldüğü iki yıllık verilerin yanında uzun yıllar ortalamasına ait iklim verileri (yağış, sıcaklık ve nisbi nem) Çizelge 1 'de verilmiştir.

Çizelge 1 incelendiğinde, ortalama sıcaklık ve nisbi nem değerleri bakımından iki yıllık değerler ile uzun yıllar değerleri arasında benzerlik olduğu, toplam yağış miktarı açısından ise vejetasyon süresince 2013 ve 2014 yılları yağış toplamının uzun yıllar yağış toplamından sırasıyla 2 ve 4 kat daha fazla yağış aldığı görülmüştür.

Çalışmada materyal olarak Geçit Kuşağı Tarımsal Araştırma Enstitüsü Müdürlüğü tarafından
2009 yılında tescil ettirilmiş olan Azkan nohut çeşidi kullanılmıştır. Çalışma tesadüf blokları deneme desenine uygun olarak dört tekerrürlü olarak yapılmıştır. Ekim zamanları bloklara kura çekilerek yerleştirilmiştir. Ekim işlemi el ile 5 metre uzunluğunda oluşturulan parsellere dört sıra halinde ekilmiştir. Ekim işlemleri Kasım, Şubat ve Mart ayları olmak üzere üç farklı zamanda yapılmıştır. Ölçümler bitkiler çıkıştan itibaren çiçeklenme sonuna kadar 6 kez yapılmıştır. Bitkilerde ölçüm işlemleri yapılırken, her parselden 10 adet bitki alınarak topraktan dikkatlice çıkarılmış ve laboratuvara getirilerek kökleri ince süzgeçli bir kapta dikkatli bir şekilde yıkanmıştır. Böylece kök kaybının olmamasına dikkat edilmiştir. Burada kök taze ağırlıkları, taze kökler hassas terazide tartılarak belirlenmiş olup, aynı materyal $105{ }^{\circ} \mathrm{C}$ 'de kök ağırlık değişimi sabitleneceği kadar etüvde bekletilmiştir. Etüvden çıkarılan kök materyali hassas terazide tartılarak kök kuru ağırlığı belirlenmiştir. Elde edilen verilere iki, üç ve dört parametreleri Weibull modelleri uygulanmıştır. Bunlar Çizelge 3'te gösterilmiştir (Weibull, 1951; Mendenhall ve Hader, 1958; Seber ve Wild, 1989).

Çizelge 3. Çalışmada kullanılan modeller ve bazı özellikleri

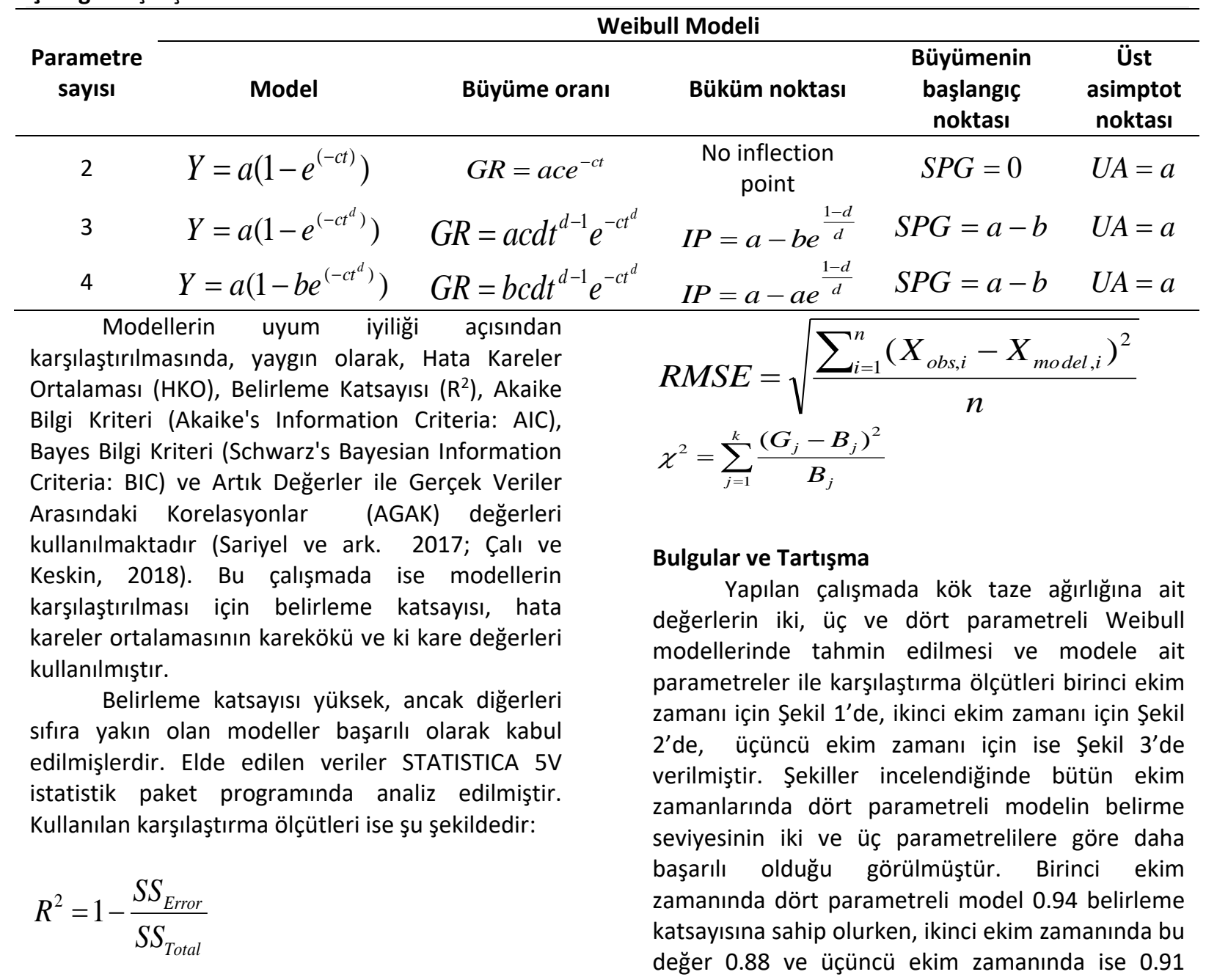


olmuştur. Ikinci ekim zamanın tanımlanmasının biraz daha düşük olduğu görülmüştür. Birinci ekim zamanının da büyümenin daha yavaş ve üçüncü ekim zamanında ise büyümenin daha hızlı olması tanımlama değerlerini etkilemiştir. Íkinci ekim zaman ise normal büyüme aşamalarını süresinde tamamladığından tanımlama başarısı daha yüksek olmuştur. Üçüncü ekim zamanında ise tanımlama biraz daha düşmüştür.

Ekim zamanları içinde ikinci ekim zamanı 0.94 ortalama belirleme katsayısına sahip olurken, birinci ekim zamanı 0.90 ve üçüncü ekim zamanı ise 0.88 değeri ile üçüncü sırada yer almıştır. Hata miktarları bakımından incelendiğinde de en düşük değer 2.914 ile birinci ekim zamanında gözlenmiştir. Bunu 3.857 değeri ile ikinci ekim zamanı ve 5.247 ile de üçüncü ekim zamanı izlemiştir. Bu sonuçlar belirleme katsayıları ile uyum içindedir. Belirleme katsayısı arttıkça hata azalır. Elde edilen sonuçlar da bunu teyit etmektedir. Ki kare değerleri dikkate alındığında iki parametreli modellerde önemlilik görülürken, üç ve dört parametrelilerde önemliliğe rastlanılmamıştır. Karşılaştırma ölçütlerinin tümü üzerinde değerlendirme yapıldığında ikinci ekim zamanında dört parametreli modelin en başarılı model olduğu söylenebilir. Bunu üç parametreli model izlerken başarısızlık ise iki parametreli modelde gerçekleşmiştir. Elde edilen sonuçlara göre kök taze ağırlığının ikinci ekim zamanında gelişimi açısından ekolojik isteklerini daha rahat bir şekilde karşıladığı

anlaşılmaktadır.

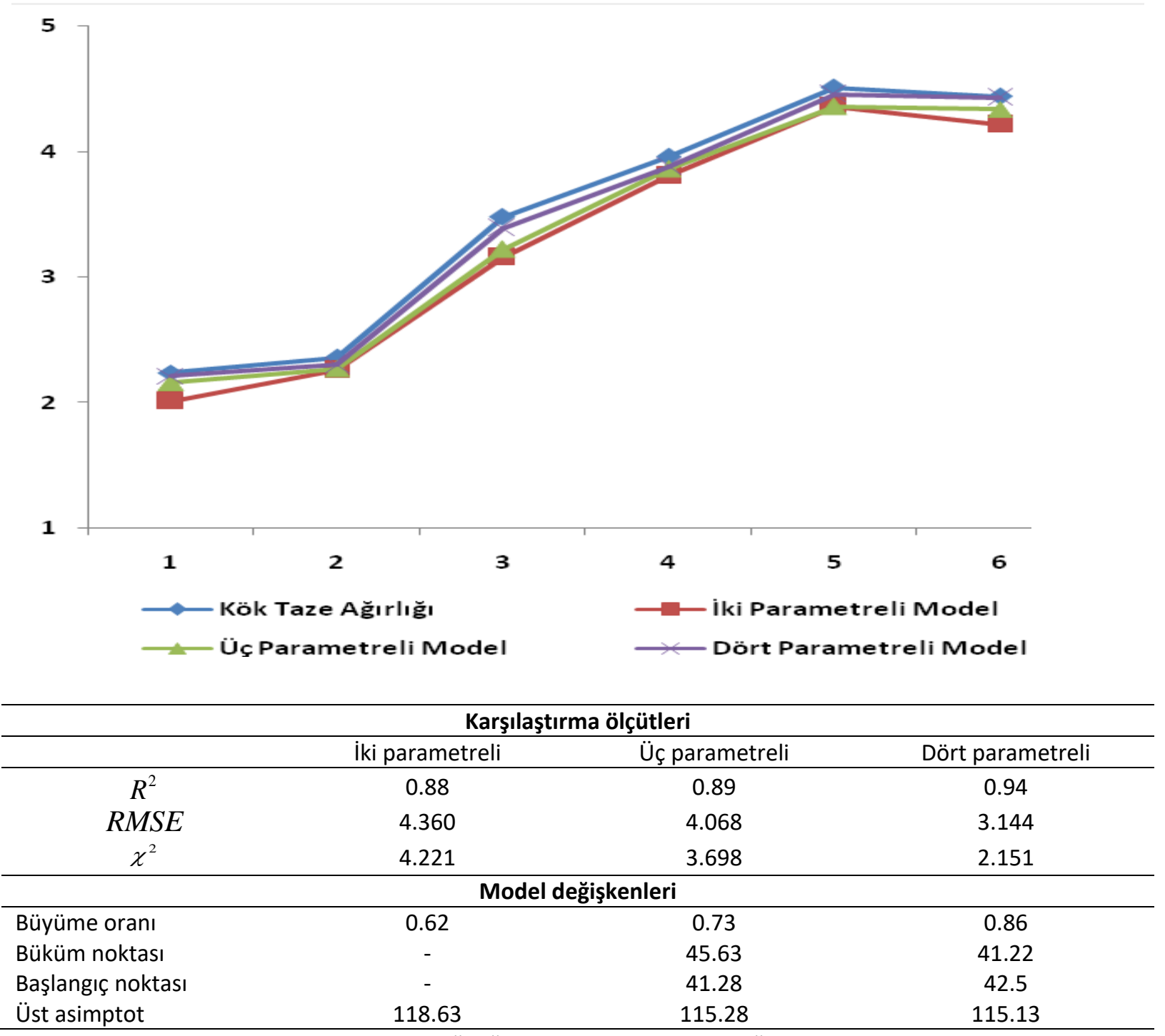

Şekil 1. Birinci ekim zamanındaki kök taze ağırlığına ait Weibull büyüme eğrileri, karşılaştırma ölçütleri ve model değişkenleri. 


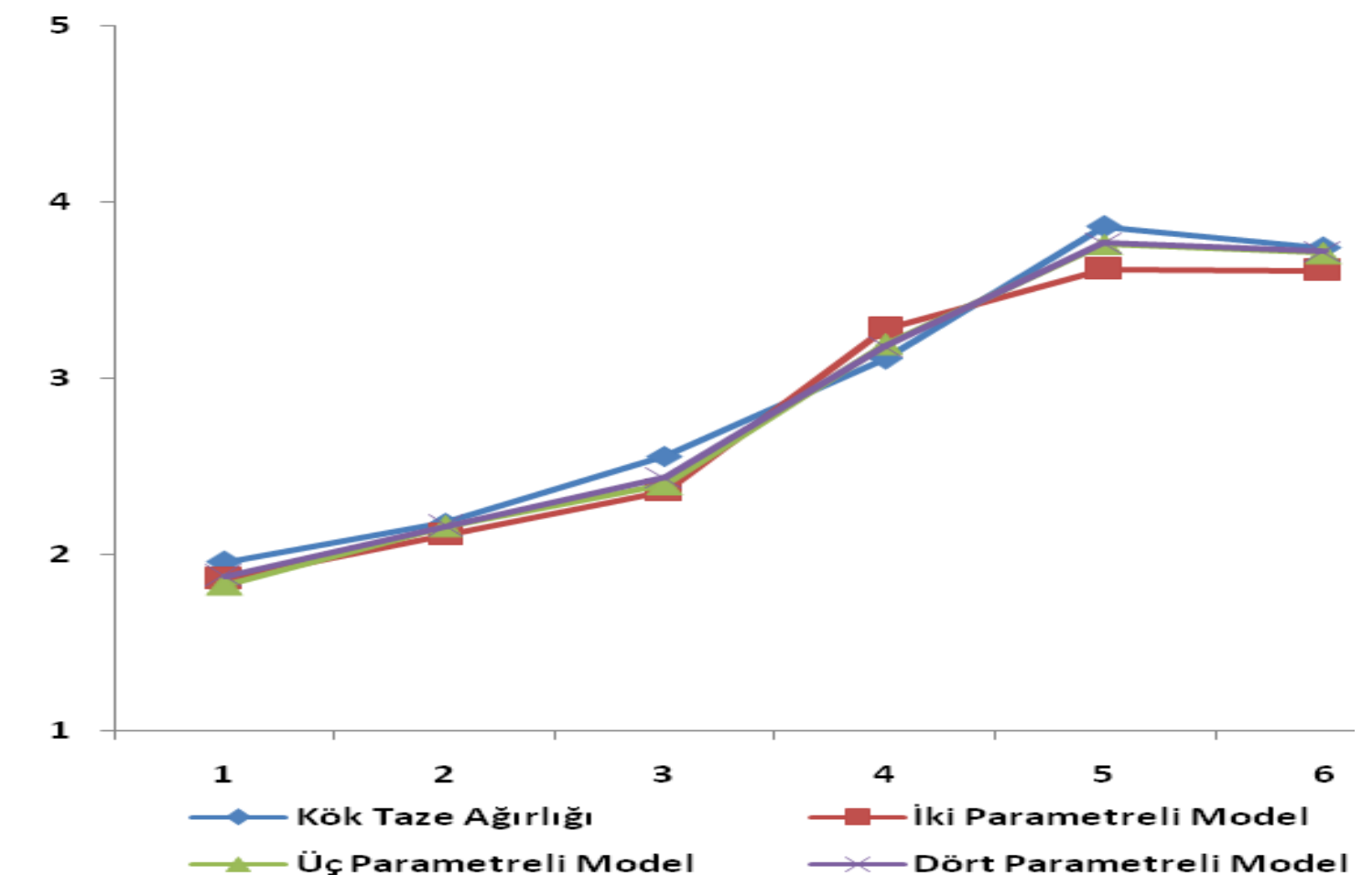

\begin{tabular}{cccc}
\hline & \multicolumn{2}{c}{ Karşılaştırma ölçütleri } \\
\hline$R^{2}$ & iki parametreli & Üç parametreli & Dört parametreli \\
$R M S E$ & 0.92 & 0.93 & 0.97 \\
$\chi^{2}$ & 3.502 & 3.086 & 2.155 \\
& 2.637 & 2.412 & 1.961 \\
\hline Büyüme oranı & \multicolumn{2}{c}{ Model değişkenleri } \\
Büküm noktası & 0.74 & 0.79 & 0.88 \\
Başlangıç noktası & - & 54.26 & 50.5 \\
Üst asimptot & - & 40.26 & 41.20 \\
\hline
\end{tabular}

Şekil 2. İkinci ekim zamanındaki kök taze ağırlığına ait Weibull büyüme eğrileri, karşılaştırma ölçütleri ve model değişkenleri.

Model değişkenleri bakımından incelendiğinde bulgular arasında da ciddi değişimlerin olduğu görülmektedir. Büyüme oranı bakımından üçüncü ekim zamanı $0.81^{\prime}$ lik ortalama oran değeri ile ilk sırada yer almıştır. Bunu 0.80 oran değeri ile ikinci ve 0.74 oran değeri ile birinci ekim zamanı elde etmiştir. Dikkat edilirse büyüme oranı değerleri ekim zamanı ilerledikçe artmaktadır. Ekimin erkene alınması büyüme oranının da yavaşlamasına sebep olmaktadır. Bu vejetasyon süresinin kısalması ve bitkilerin bir an önce olgunlaşmaya doğru yönelmelerinden kaynaklanmaktadır. Büyüme oranları en yüksek dört parametreli modelde tahmin edilirken, en düşük ise iki parametreli modelde tahmin edilmiştir.

Büküm noktası bitkilerin büyüme ve gelişmelerinin tespit edilmesinde önemli bir parametre olarak kabul edilir. iki parametreli modelde büküm parametresi bulunmamaktadır. Bu nedenle tahminleme yapılamamıştır. Ancak elde edilen büküm noktası parametrelerine göre ikinci ekim zamanının 52.20 değer ile ilk sırada yer aldığı, bunu 43.43 değeri ile ilk ekim zamanının izlediği görülmüştür. Üçüncü ekim zamanı ise 38.18 değeri ile son sırada yer almıştır. Büyümenin başladığı nokta olarak da yine birinci ekim zamanı 41.89 değeri ile ilk sırada yer alırken, ikinci ekim zamanı 40.79 ve üçüncü ekim zamanı ise 35.71 değeri ile ise son sırada yer almıştır.

Büyümenin başlangıç noktası olarak ilk ekim zamanında daha yüksek başlangıç noktası tespit edilmiştir. Üçüncü ekim zamanında ise en düşük değer elde edilmiştir. Bu sonuç yine vejetasyon süresinin uzunluğu ile ilgili olduğunu ortaya koymaktadır. Üst asimptot değeri ise bitkilerde her şey yolunda gittiği takdirde bitkinin alabileceği en üst değeri ifade etmektedir. Burada ölçülen kök 
ağırlığı olduğundan tüm bitkinin beklenen en yüksek kök ağırlığını ifade etmektedir. Burada en yüksek değer ikinci ekim zamanında 126.66 ortalama değer ile elde edilirken, bunu 116.35 değeri ile birinci ekim zamanı izlemiştir. Üçüncü ekim zamanı ise 95.88 değeri ile son sırada yer almıştır. İki parametreli modellerin diğerlerine göre daha yüksek değere sahip oldukları görülürken, dört parametreli modellerin ise en az değere sahip oldukları görülmüştür. Bu aslında ikinci ekim zamanının bitkiler için uygun bir zaman olduğunu göstermesi bakımından önemlidir.

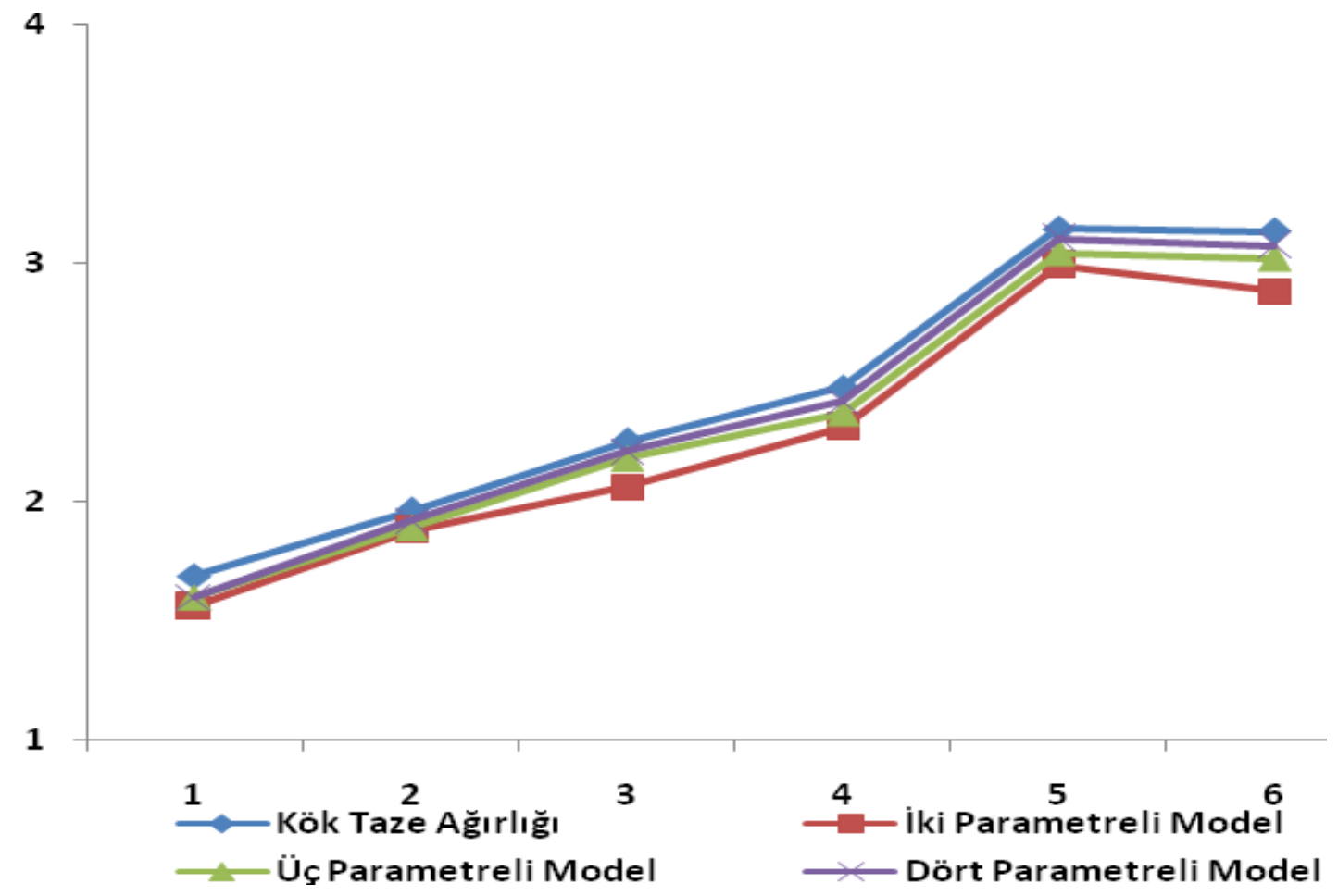

\begin{tabular}{cccc}
\hline & \multicolumn{2}{c}{ Karşılaştırma ölçütleri } & Dört parametreli \\
\hline$R^{2}$ & İki parametreli & Üç parametreli & 0.91 \\
$R M S E$ & 0.84 & 0.88 & 4.962 \\
$\chi^{2}$ & 5.662 & 5.117 & 5.337 \\
\hline \multicolumn{4}{c}{ Model değişkenleri } \\
\hline Büyüme oranı & 6.351 & 5.984 & 0.90 \\
Büküm noktası & 0.75 & 39.14 & 37.21 \\
Başlangıç noktası & - & 35.24 & 36.18 \\
Üst asimptot & - & 95.44 & 94.36 \\
\hline
\end{tabular}

Şekil 3. Üçüncü ekim zamanındaki kök taze ağırlığına ait Weibull büyüme eğrileri, karşılaştırma ölçütleri ve model değişkenleri.

Yapılan çalışmada kök kuru ağırlığına ait değerlerin iki, üç ve dört parametreli Weibull modellerinde tahmin edilmesi ve modele ait parametreler ile karşılaştırma ölçütleri birinci ekim zamanı için Şekil 4'de, ikinci ekim zamanı için Şekil $5^{\prime}$ de, üçüncü ekim zamanı için ise Şekil 6'da verilmiştir.

Kök kuru ağırlıkları bakımından incelendiğinde kök taze ağrılığında görülen farklılıklara benzer sonuçların elde edildiği görülmektedir. En yüksek ortalama belirleme katsayısı değeri 0.94 değeri ile ikinci ekim zamanında tespit edilirken, bunu 0.92 ile ikinci ve 0.86 değeri ile de üçüncü ekim zamanı izlemiştir. Bütün zamanlar dikkate alındığında dört parametreli modelin daha başarılı tanımlama değerine sahip olduğu görülmektedir. Parametre sayısının artması elde edilen verinin özelliklerini daha net ortaya koyduğu için tanımamla başarısı da artmaktadır. Hata değerleri bakımından en yüksek 
ortalama hata değeri 7.359 ile üçüncü ekim zamanında tespit edilirken, en düşük değer ise ikinci ekim zamanında 2.914 ile elde edilmiştir. Hata değeri arttıkça belirleme katsayısı yükselmektedir. Ki kare değerleri bakımından değerlendirildiğinde taze ağırlığın sahip olduğu değerlerin çok üzerinde olduğu ve tümünün önemli çıktığı görülmüştür. Bu değişkenler arasındaki farklılığın kuru ağırlıkta taze ağırlığa göre daha yüksek olduğu görülmektedir.

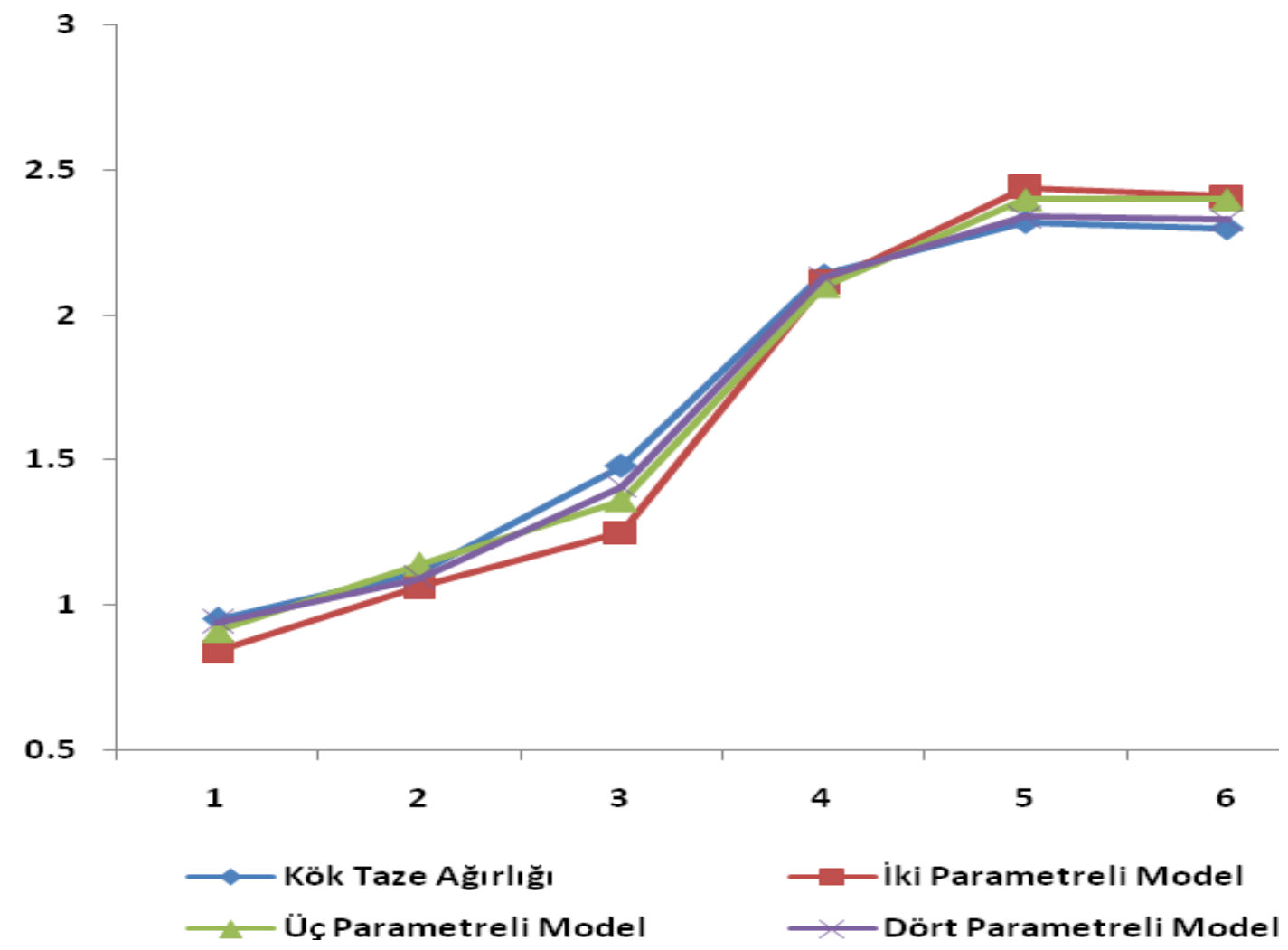

\begin{tabular}{|c|c|c|c|}
\hline \multicolumn{4}{|c|}{ Karşılaştırma ölçütleri } \\
\hline & İki parametreli & Üç parametreli & Dört parametreli \\
\hline$R^{2}$ & 0.90 & 0.92 & 0.94 \\
\hline$R M S E$ & 3.168 & 2.961 & 2.814 \\
\hline$\chi^{2}$ & 2.036 & 1.967 & 1.611 \\
\hline \multicolumn{4}{|c|}{ Model değişkenleri } \\
\hline Büyüme oranı & 0.29 & 0.28 & 0.30 \\
\hline Büküm noktası & & 22.03 & 24.12 \\
\hline Başlangıç noktası & & 20.11 & 20.16 \\
\hline Üst asimptot & 56.20 & 54.18 & 53.27 \\
\hline
\end{tabular}

Şekil 4. Birinci ekim zamanındaki kök kuru ağırlığına ait Weibull büyüme eğrileri, karşılaştırma ölçütleri ve model değişkenleri.

Büyüme oranı bakımından incelendiğinde en yüksek ortalama büyüme oranı 0.50 değeri ile ikinci ekim zamanında elde edilmiştir. Bunu 0.49 değeri ile üçüncü ekim zamanı izlemiştir. Birinci ekim zamanı ise 0.29 ile oldukça düşük değere sahip olmuştur. Birinci ekim zamanında sürenin uzun olması ve vejetasyon süresinin bir kısmının kışa denk gelmesi bunda etkili olmuş olabilir. Büküm noktası kuru ağırlığa göre oldukça düşmüştür. Bu durumun kuru ağırlık bakımından taze ağırlığa göre daha düşük değerler alınmasından kaynaklanmış olabileceği tahmin edilmektedir. 


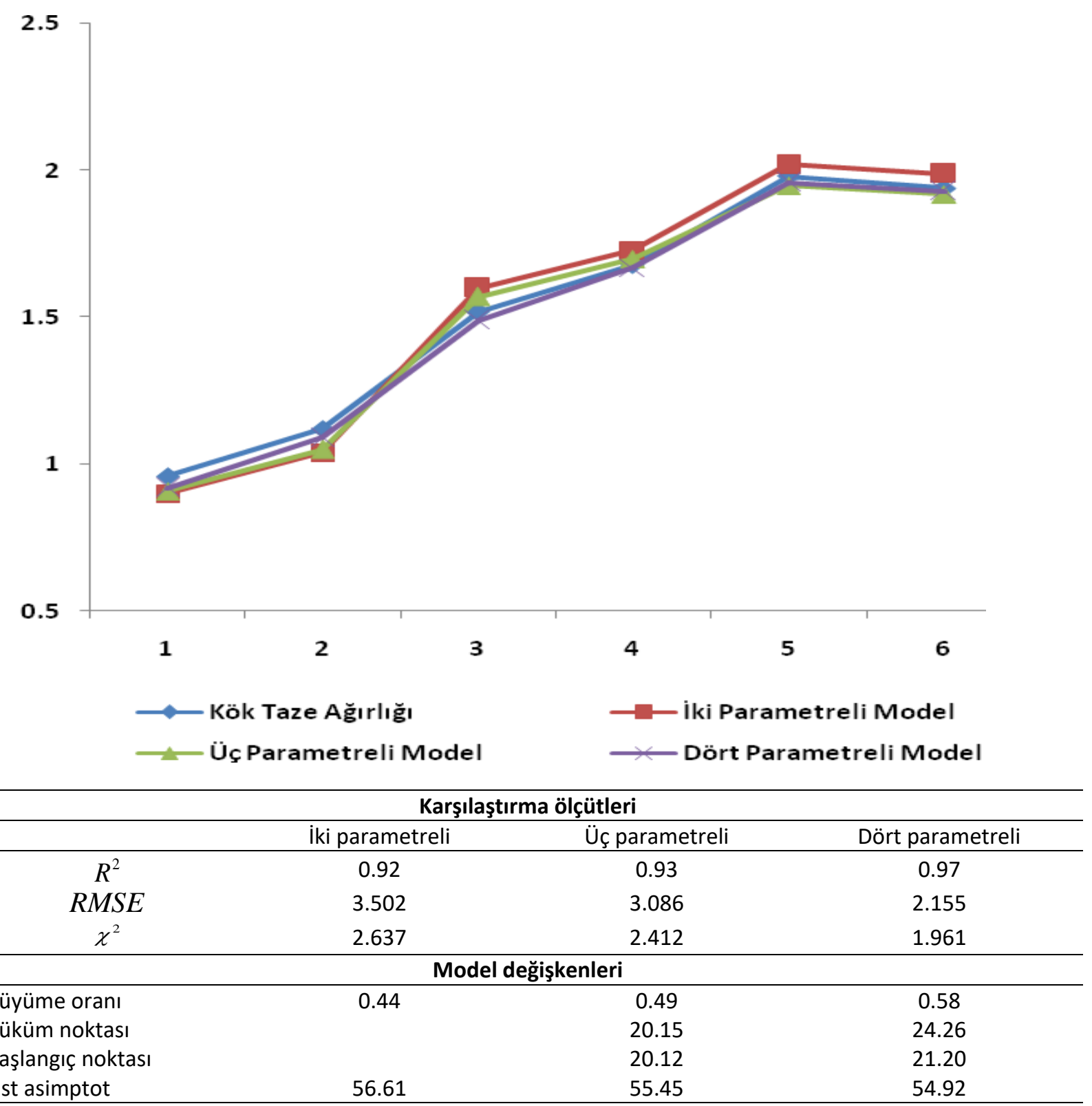

Şekil 5. Birinci ekim zamanındaki kök kuru ağırlığına ait Weibull büyüme eğrileri, karşılaştırma ölçütleri ve model değişkenleri.

Bitkide su miktarı ne kadar yüksek olursa kuru madde birikimi de o kadar düşük olmaktadır. En yüksek ortalama büküm noktası 23.08 değeri ile birinci ekim zamanında tespit edilirken, bunu 22.21 ve 21.72 değerleri ile ikinci ve üçüncü ekim zamanları izlemiştir. Zaman ilerledikçe büküm noktasının azaldığı görülmektedir. Bu zamanla bitki boyunda yaşanan kısalmadan kaynaklanmaktadır. Yetiştirme sezonunun kısalığı bitkileri istenilen seviyede boy uzatmalarına imkân vermemektedir.

Büyümenin başlangıç noktası incelendiğinde en yüksek ortalama başlangıç noktasının 20.66 değeri ile ikinci ekim zamanında olduğu bunu 20.09 değeri ile ikinci ekim zamanının izlediği görülmektedir. En düşük başlangıç noktası değeri ise 19.83 ile üçüncü ekim zamanında belirlenmiştir. Büyüme oranı, büküm noktası ve büyümenin başlangıç noktaları açısından tümünde dört parametreli modelin daha yüksek değerler tahminlediği görülmektedir. Üst asimptot olarak bakıldığında ise ortama değer olarak 55.66 değeri ile ikinci ekim zamanında en yüksek değer tahmin edilirken, 49.88 değeri ile üçüncü ekim zamanında en düşük değer elde edilmiştir. 


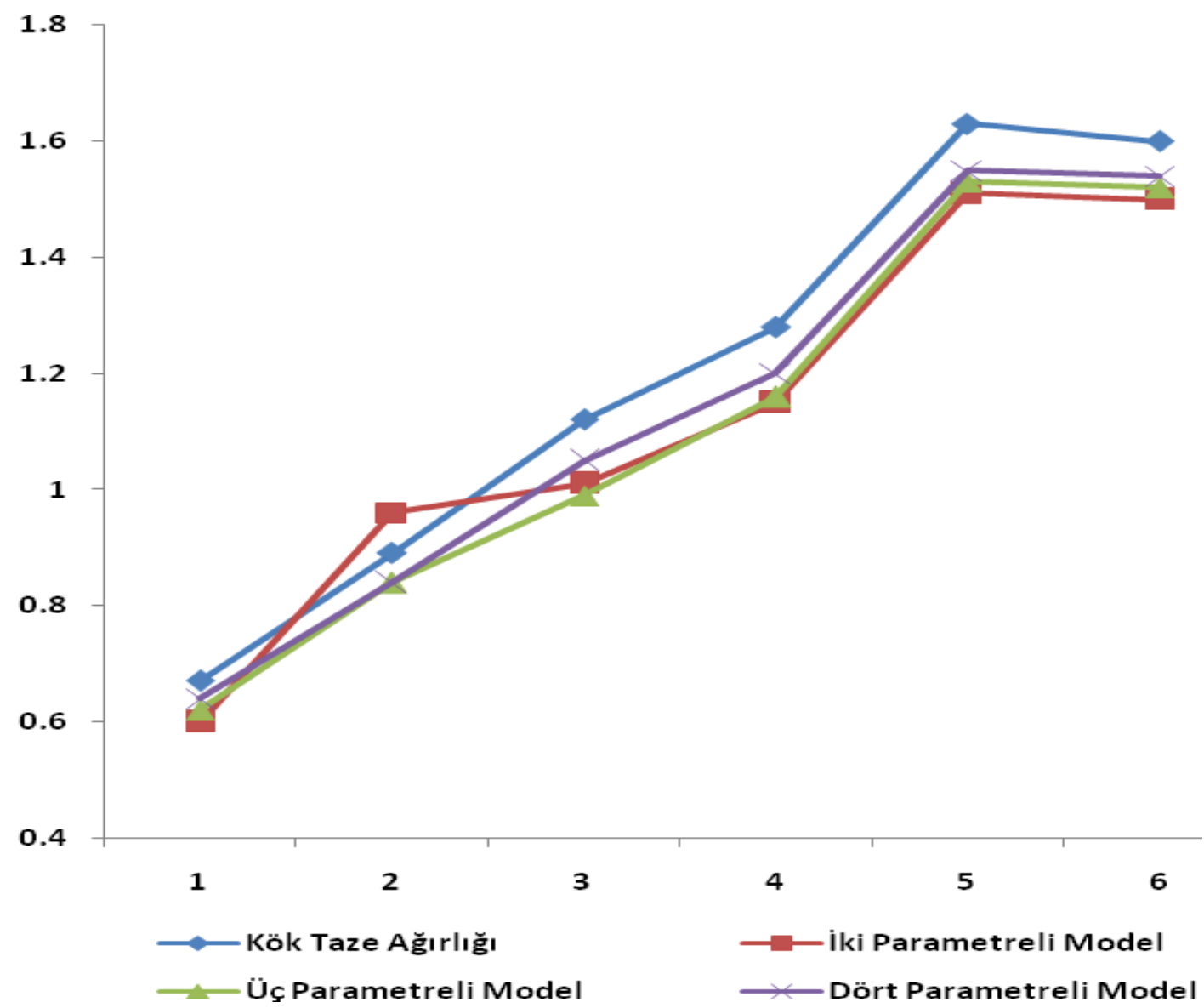

\begin{tabular}{|c|c|c|c|}
\hline \multicolumn{4}{|c|}{ Karşılaştırma ölçütleri } \\
\hline & iki parametreli & Üç parametreli & Dört parametreli \\
\hline$R^{2}$ & 0.83 & 0.84 & 0.87 \\
\hline$R M S E$ & 7.658 & 7.412 & 7.008 \\
\hline$\chi^{2}$ & 9.502 & 8.644 & 8.268 \\
\hline \multicolumn{4}{|c|}{ Model değişkenleri } \\
\hline Büyüme oranı & 0.46 & 0.51 & 0.52 \\
\hline Büküm noktası & & 21.17 & 22.26 \\
\hline Başlangıç noktası & & 19.54 & 20.11 \\
\hline Üst asimptot & 51.23 & 49.87 & 48.55 \\
\hline
\end{tabular}

Şekil 6. Birinci ekim zamanındaki kök kuru ağırlığına ait Weibull büyüme eğrileri, karşılaştırma ölçütleri ve model değişkenleri.

Nohut bitkilerinin su kullanım etkinliğinin ve transpirasyon oranının yüksek olmasına karşın, derin kök yağısı nedeniyle olumsuz iklim şartlarına ve kurağa oldukça dayanıklı olarak bilinir (Saxena, 1984). Bu özelliğinin zamanlara göre bazı değişiklikler gösterdiği ve geç dönemde ekim işleminin yapılmasının bitkinin başta kök olmak üzere bütün özelliklerini baskılayarak büyüme ve gelişmeyi önemli ölçüde azaltmaktadır (Smithson ve ark. 1985). Bunun nedeni ise vejetasyon süresinin kısa olması nedeniyle bitkilerin gerektiği ölçüde vejetatif olgunlaşmayı sağlamadan generatif olgunluğa girmeye zorlanmalarından kaynaklanmaktadır. Bunda en büyük payı kök gelişiminin yeterinde gelişmemesinden kaynaklanmaktadır (Karadavut ve Tozluca, 2005). Bunun sonucu olarak ta başta verime etki eden karakterlerde ve daha sonra da verimde önemli kayıplar görülmektedir (Açıkgöz, 1987). Geç yapılan ekimlerde kök gelişiminin ve vejetatif yapının tam olarak olgunlaşmamasından dolayı verim yarıya yakın düşmektedir (Özdemir ve Karadavut, 2003). Ancak özellikle antraknoz gibi hastalıklara bulaşmamak için ekim zamanlarında sıklıkla değişiklik yapılması gerekliliği ortaya çıkmaktadır. Bunun içinde üreticilerin verim ile birlikte verime etki eden karakterlerdeki azalmaları göz önüne almaları gerekir (Meyveci ve ark., 1993). 
Biçer ve ark. (2017) yaptıkları çalışmada, nohut bitkilerinde ekim zamanının çiçeklenme ve olgunlaşma süresi, bitki boyu, bitkide bakla ve tane sayısı, 100 tane ağırlığı ve tane verimine etkisini önemli bulunmuşlardır. Özelikle ekimin erkene alınmasını önermişlerdir. Erken ekim her zaman için vejetasyon süresini uzattığından aynı zamanda tanımlama başarısında yüksek olmasına neden olmaktadır. Karadavut ve ark (2010c) büyüme ve gelişmenin başarılı bir şekilde tanımlanabilmesi için vejetasyon süresinin önemli olduğu belirtmişlerdir. Karadavut ve ark. (2010d), ise büyümenin fonksiyonel olabilmesi ile tanımlamanın başarılı olabileceğini ve bunun içinde bitkilerin gelişme evrelerinin yakından izlenmesinin gerekli olduğunu belirtmiştir. Aynı zamanda yetişme sürelerinin tanımlamayı doğrudan etkileyebildiğini belirtmişlerdir. Yapılan bu çalışmada elde edilen sonuçlar bakımından araştırmacılar ile ciddi alamda benzerlikler bulunmaktadır. Özellikle ekim zamanının geciktirilmesinin erken ekime göre tanımlama başarısını düşürmesi bütün araştırmacıların öncelikli olarak üzerinde durduğu konu olarak görülmüştür.

\section{Sonuç ve Öneriler}

Farklı ekim zamanlarında yetiştirilen nohut bitkilerinin iki, üç ve dört parametreli Weibull modelleri ile tahmin edilebilmesi için yürütülen çalışma sonucunda bütün Weibull modellerinin genel olarak başarılı tahminleme yaptığı görülmüştür. En başarılı tahminleme ise dört parametreli Weibull modelinde tespit edilmiştir. Ekim zamanı ilerledikçe bitkilerin büyüme ve gelişmeleri için gerekli sürenin azalmasından dolayı diğer zamanlara göre daha hızlı büyümek zorunda kaldıkları ve bu nedenle bazı özellikler bakımından diğer zamanlara göre farklıklar gözlendiği görülmüştür. Ancak en uygun yetiştirme döneminin ikinci ekim zamanını şubat ayı olduğu söylenebilir. Bölgede yetiştiriciliği yapılacak nohut bitkilerinde ikinci ekim zamanının uygunluğu önerilebilir.

\section{Kaynaklar}

Açıkgöz, N. 1987. Nohut Tarımı. T.C. Tarım Orman ve Köy İşleri Bakanlığı, Ege Bölge Zirai Araştırma Enstitüsü Müdürlüğü Yayınları, No: 76, s.21., İzmir.

Adams, F., Moore, B.L. 1983. Chemical factors affecting root growth in subsoil horizons of coastal plain soils. Soil Sci. Soc. Am. J., 47: 99-102.

Altın, N., Bora, T. 2005. Bitki Gelişimini uyaran kök bakterilerinin genel özellikleri ve etkileri. Anadolu (Journal of AARI), 15(2): 87-103.

Biçer, B.T., Albayrak, Ö., Akıncı, C. 2017. Farklı ekim zamanlarının nohutta verim ve verim unsurlarına etkisi. ADÜ Ziraat Fakültesi Dergisi, 14(1): 51-57.

Çalı, B., Keskin, İ. 2018. Comparison of growth curve models in hair goat kids. II. International Eurasian Agriculture and Natural Sciences Congress, 11-15 September, Baku, Azerbaijan.

El-Ghamery, A.A., El-Kholy, M.A., ElYousser, A. 2003. Evaluation of cytological effects of $\mathrm{Zn}+2$ in relation to germination and root growth of Nigella sativa L. and Triticum aestivum L. Mutation Research, 537: 29-41.

Fekeduleng, D., Mac Siurtain, M.P., Colbert, J.J. 1999. Parameter estimation of nonlinear growth models in froeastry. Silva Fenicca, 33(4): 327-336.

Foy, C.D. 1992. Soil chemical factors limiting plant root growth. Advances in Soil Science, 19: 97-149.

Gür, N., Topdemir, A., Munzuroğlu, Ö., Çobanoğlu, D. 2004. Ağır metal iyonlarının $(\mathrm{Cu}+2, \mathrm{~Pb}+2$, $\mathrm{Hg}+2, \mathrm{Cd}+2)$ Clivia $s p$. bitkisi polenlerinin çimlenmesi ve tüp büyümesi üzerine etkileri. Fırat Üniversitesi Fen ve Matematik Bilimleri Dergisi, 16(2): 177-182.

Hodge, A., Berta, G., Doussan, C., Merchan, F., Crespi, M. 2009. Plant root growth, architecture and function. Plant Soil, 321: 153-187.

Jain, R., Srivastava, S., Madan, V.K. 2000. Influence of chromium on growth and cell division of sugarcane. Indian J. Plant Physiol., 5: 228231.

Kacar, B. 1995. Bitki ve Toprağın Kimyasal Analizleri 3: Toprak Analizleri. Ankara Üniversitesi Ziraat Fakültesi Eğitim Araştırma ve Geliştirme Vakfı Yayınları, No. 3, 705 s.

Karadavut, U., Tozluca, A. 2005. Growth analysis some characters in rye plants (Secale cereale L.) Growth of root and upper ground parts. J. Crop Res., (2): 1-10.

Karadavut, U., Palta, Ç., Kökten, K., Bakoğlu, A. 2010a. Comparative study on some nonlinear growth models for describing leaf growth of maize. Int. J. Agric. Biol., 12: 227230.

Karadavut, U., Genç, A., Tozluca, A., Palta, Ç. 2010b. Silajlık ve danelik mısırlarda kuru madde birikiminin bazı matematiksel büyüme modelleri ile analizi. Tarım Bilimleri Dergisi, 16: 89-96.

Karadavut, U., Palta, Ç., Kökten, K., Bakoğlu, A. 2010c. Comparative study on some nonlinear growth models for describing leaf growth of maize. Int. J. Agric. Biol., 12: 227230. 
Karadavut, U., Kökten, K., Kavurmacl, Z. 2010d. Comparison of relative growth rates in silage corn cultivars. Asian Journal of Animal and Veterinary Science, 5(3): 223-228.

Mahanta, D.J., Borah, M. 2014. Parameter estimation of Weibull growth models in forestry. International journal of Mathematics Trends and Technology. 8(3): 157-163.

Malamy, J.E. 2005. Intrinsic and environmental response pathways that regulate root system architecture. Plant Cell Environ., 28: 67-77.

Mendenhall, W., Hader, R.J. 1958. Estimation of parameters of mixed exponentially distributed failure time distributions from censored life test data. Biometrica, 45: 504520.

Meyveci, K., Eyüpoğlu, H., Karagüllü, E. 1993. Orta Anadolu bölgesinde bazı nohut çeşitleri için uygun ekim zamanının belirlenmesi. Tarla Bitkileri Merkez Araştırma Enstitiüsü, Ankara.

Murthy, D.N.P., Xie, M., Jiang, R. 2004. "Weibull Models", Wiley Series in Probability and Statistics, United States of America.

Özdemir, S., Karadavut, U. 2003. The performance of autumn sowing over spring sowing of chickpea in the temperate region. Tr. J. of Agriculture and Forestry, (27): 345-352.

Prasad, T.V.R., Krishnamurthy, K., Kailasam, C. 2008. Functional crop and cob growth models of maize (Zea mays L.) cultivars. J. Agron. Crop Sci., 194: 208-212

Ratkowsky, D.A. 1983. Nonlinear Regression Modelling. Marcel Dekker, New York, USA.

Reynolds, H.L., D'Antonio, C. 1996. The ecological significance of plasticity in root weight ratio in response to nitrogen: Opinion. Plant Soil, 185: 75-97.

Romerio, R.S. 2000. Preliminary results on PGPR research at the Universidade Federal de Viçosa, Brazil. Fifth International PGPR Workshop, 29 October-3 November, Cordoba-Argentina.

Saleque, M.A., Kirk, G.J.D. 1995. Root-induced solubilization of phosphate in the rhizosphere of lowland rice. New Phytol., 129: 325-336.

Sariyel, V., Aygun, A., Keskin, i. 2017. Comparison of growth curve models in partridge. Poultry Science, 96: 1635-1640.

Saxena, N.P. 1984. Chickpea in the Physiology of Tropical Field Crops (Goldsworthy, P.R. and Fisher, N.M., eds.), pp. 419- 452. John Wiley and Sons Ltd, UK.
Seber, G.A.F., Wild, C.J. 1989. Nonlinear Regression. A John Willey \& Sons Publications.0-471-47135-6.

Smithson, J.B., J.A. Thompson, R.J. Summerfield, 1985. Chickpea. Grain Legume Crops (Summerfield, R. J. and E. H. Roberts, eds.)., pp. 315-345, Collins, London.

Singh, M.B., Bhalla, P.L. 2006. Plant stem cells carve their own niche. Trends Plant Sci., 11: 241-246.

Weibull, W. 1951. A statistical distribution function of wide applicability. Journal of Applied Mechanics, 18: 293-296. 